\title{
The Water for Food Global Institute at the University of Nebraska: Growing More Food with Less Water - an Opportunity for Collaboration
}

\author{
Prem S. Paul
}

Vice Chancellor for Research and Economic Development, University of Nebraska-Lincoln Monica Norby

Assistant Vice Chancellor for Research, University of Nebraska-Lincoln

$\mathrm{T}$ he Challenge: Global agricultural productivity has increased dramatically during the past 50 years. Fueled by improved crop varieties, new irrigation technologies, and improved agricultural practices, the global food supply has kept pace with a rapidly growing population. Yet, today we face the possibility of global food scarcity.

By 2050, the world population is expected to increase 40 percent, and the demand for food will double. Population growth is just one factor in this increasing demand. Rising incomes in the developing world mean people are eating more meat and dairy products, which require much more grain. Corn, soybeans, and other crops are being diverted to biofuel production in the developed nations. Worldwide, prime agricultural land is being lost to urban expansion. All of these factors are converging to create food scarcity.

This escalating demand on agriculture to produce food, feed, fiber, and fuel will exert intense pressures on the quantity and quality of our water resources. Globally, most fresh water is used to produce food. Agriculture is responsible for 75 percent of all water withdrawals and 86 percent of total human consumptive use, and the vast majority of that water is used for irrigating crops.

Already, water shortages are occurring in many of the world's major food production areas, and in the future burgeoning industrial and municipal demands will shift more water away from agriculture. In a time when

agriculture is being asked to produce more food for a growing population, demand for water is growing, and a changing global climate holds unknown risks. We must grow more food with less water.

The daunting issues surrounding water use are globally important. This is one of the largest and most complex challenges facing our nation and the global community. It demands our best ideas and an interdisciplinary approach, not only to find ways to produce more crop per drop but also to change human attitudes and behaviors that prevent us from using water efficiently. 
Although many organizations in government, academia, and the private sector are working to address global water issues and to improve crop production systems, the University of Nebraska recognized that there still is a critical need for a focused global effort to bring together expertise from many disciplines, including basic and applied water and agricultural sciences and economic and behavioral sciences, to conduct research focused on producing more food per unit of water. To meet that need, the University is establishing the Water for Food Institute, a global research, education, and policy analysis institute committed to helping the world efficiently use its limited fresh water resources to ensure the food supply for current and future generations.

\section{Why Nebraska?}

For more than a century, the University of Nebraska has been a leader in research on water, agriculture, and the management of critical natural resources. This leadership grew naturally from Nebraska's position as a steward of vast natural resources. The native grasslands and farmlands of Nebraska comprise one of the most productive agricultural areas in the world - a level of production made possible by a wealth of water resources that includes numerous rivers and streams and the High Plains Aquifer, one of the largest aquifers in the world, containing 3.25 billion acre-feet of water, 66 percent of it in Nebraska. These resources enable the state's irrigated crop production, placing it first in the U.S. in irrigated crop acres and fourth in food production, and giving Nebraska global significance as a food producer.
Center pivot irrigation systems were invented in Nebraska, and the state is now home to the world's four largest pivot manufacturers. The state is a leader in innovative policies to manage and conserve surface and groundwater resources. This strong knowledge base developed by the public and private sectors, coupled with a long history of research, education, and outreach focused on water and agriculture, positions the University and its partners to contribute innovative solutions to the global challenges of growing more food with less water and managing limited water resources in a thirsty world.

\section{Developing a Big Vision}

The state has historically made significant investments in the University of Nebraska and has continued to do so in challenging economic times. Currently, more than 160 faculty have expertise related to water and food. The University of Nebraska Board of Regents and leaders in agriculture and industry within the state have been extremely aware of both the challenges associated with water and its importance to the state's economic security and to global food security. They challenged university leaders and faculty to think big about what the university can do to provide global leadership to address issues pertaining to water.

A faculty taskforce was formed to discuss issues related to water, map institutional expertise in those areas, and develop a vision for moving forward. The committee recommended that we establish a global institute with a focus on water for food production. As a first step, they recommended we hold an international conference to better learn 
about the challenges and to gather input from diverse experts in food and water on the need for such an institute and the ways to organize it. The Future of Water for Food Conference was held in May, 2009, and co-hosted by Jeff Raikes, CEO of the Bill \& Melinda Gates Foundation and James B. Milliken, President of the University of Nebraska. It was cosponsored by the Robert B. Daugherty Foundation and the University of Nebraska Foundation.

The conference brought together more than 230 scientists and decisionmakers representing universities, industry, government, and nongovernmental organizations from throughout the U.S. and five other countries. Conference participants addressed many aspects of the essential linkages between water and food and the most pressing issues - overuse, underuse, and inefficient use of water; water quantity and quality; water scarcity; sustainability of the resource; distribution and demand conflicts; legal and institutional barriers to management; and others - and offered ideas and recommendations for tackling the challenges.

In the keynote address, Jeff Raikes succinctly framed the issues. Agriculture and water are inseparable, Raikes said. Many approaches to water management have not worked or have been inadequate. Innovative tools and technologies are needed to address five key challenges: overuse of the water resource; underuse of the water resource; inefficient use, in the sense of not maximizing output per unit of water used; changing water demands as economies grow; and changing water supplies in the face of climate change and other challenges. Other speakers and panel sessions discussed groundwater resources; the economics of water scarcity; the challenges of managing water for agriculture in Pakistan; better tools for managing water; "green water" and "blue water;" improving drought tolerance and nutrition of crops; the importance of developing sustainability; the need to integrate the scientific, economic, legal, and social factors that affect water management and food production; and other issues.

A main goal of the conference was to explore, through a dialogue among these experts, how a global institute addressing water and food security established at the University of Nebraska could develop the programs and partnerships to effectively address these issues. A core group of 65 experts attended a half-day working session following the conference. Some of their key recommendations included:

The area of water for food is growing in importance and no organization exists nationally or internationally that is focusing exclusively on this issue. Nebraska is a good place for such an organization, and now is the right time to establish this institute.

The core mission of the institute should be to answer the question: how can we produce more food per unit of water? The answer to this question must be broadly construed and inter-disciplinary - to develop, promote, and disseminate the application of science, technology, education, policy, and human behavior research to this problem. 
The right leader (executive director) is critical.

Partnerships - with other universities, governmental agencies, NGOs, foundations, and private sector organizations nationally and internationally - are critical.

Additional information can be found in the Proceedings of the Future of Water for Food Conference, available at: http://waterforfood.nebraska.edu.

The success of the conference and the invaluable input from these international leaders confirmed the University's mission to build a global Water for Food Institute. NU President James B. Milliken led the effort to develop the concept and find funding for the proposed institute.

Establishing the Water for Food

\section{Institute}

On April 20, 2010, the University of Nebraska was fortunate to receive a $\$ 50$ million founding gift commitment from the Robert B. Daugherty Charitable Foundation to support the global Water for Food Institute. The gift, one of the largest in the University's history, was to create a multi-campus center for research, education and policy analysis relating to use of water for agriculture. Mr. Daugherty, a native Nebraskan, is the founder of Valmont Industries, one of the largest irrigation companies in the world, and is dedicated to pursuing research and technologies that will produce "more crop per drop" and to preserving our freshwater resources.

Two weeks after the gift was announced, the University held the second international Water for Food Conference, supported in part by the Gates Foundation, the Robert B.
Daugherty Foundation, and Monsanto Company. The conference drew more than 300 participants from 13 countries. Jeff Raikes again gave a keynote, saying that he believed the "...Water for Food Institute is going to be an important leader in addressing a crisis in producing food to feed the world." Other leading speakers included Pedro Sanchez of the Columbia University Earth Institute and 2002 World Food Prize laureate; John Briscoe of Harvard's Water Security Initiative; David Molden, Deputy Director General of the International Water management Institute; Robert T. Fraley, Executive Vice President and Chief Technology Officer, Monsanto Company; U.N. Panjiar, Secretary, Ministry of Water Resources, India; and 24 others. Many spoke about the Water for Food Institute and posed challenges in research, education, and policy analysis that the institute could undertake. Several potential partnership opportunities arose from the conference.

\section{Water for Food: A Global Institute}

The Vision: The Water for Food Institute is a research, education, and policy analysis institute committed to helping the world efficiently use its limited freshwater resources, with particular focus on ensuring the food supply for current and future generations.

Creating the Water for Food Institute is an exciting and extremely challenging endeavor. The expectations, and the visibility, are high. Even with the University's significant depth and breadth of expertise and the funds from the Daugherty Foundation, we know we cannot succeed alone. Partnerships are critical. The Water for Food Institute will 
be a "distributed" institute, with a core group in Lincoln and partners throughout the region and the world. These partners may be from other universities, the public sector (foundations, government agencies, NGOs), and the private sector. The Daugherty gift, while very generous, is viewed as seed funding to enable us to build capacity by funding project development, faculty and student exchanges, and educational programs. To really accomplish the institute goals, we must leverage these funds by securing funding from federal agencies, foundations, and others.

The Water for Food Institute will be governed by a board of directors chaired by the University of Nebraska president. An international advisory board will play a role in strategic planning and partnership building, and a faculty advisory board comprising representatives from all four University of Nebraska campuses will engage the various disciplines and intellectual resources of the University with the institute.

The institute will focus its research, education, and policy analysis efforts on increasing agricultural water productivity through developing new technologies, novel and improved crops, innovative management practices, studies of the human dimensions of water use, and advanced decisionmaking tools and knowledge delivery systems to inform and guide policymakers, managers, and the public. Institute programs will address the needs of production agriculture and translation to small-holder farmers, irrigated and rainfed agriculture, in both developed and developing nations.

Initial funding will be used for:

- Core leadership positions: executive director, director of research, and director of policy analysis

- International research fellows and visiting scholars

- Graduate fellow and undergraduate scholars programs

- Cooperative research programs

- Academic programs

- Seed grants for research stimulation

- Water for Food online scholarly journal

- Annual Water for Food Conference

- Administration and management

- Marketing and promotion

The Water for Food Institute will be formally established by the University of Nebraska Board of Regents in October, 2010, and the search for an executive director is underway. Discussions and the development of Memoranda of Understanding with potential partners have begun. Initial organizational efforts have included a series of faculty engagement forums to drill down into areas of faculty expertise on all four campuses; elicit ideas and input from the faculty; begin discussions of potential research, education, and policy programs; and challenge them to develop big ideas that will take the institute forward in the next five to 10 years. The work has begun. 
Sustaining and Enhancing the Research Mission: A Potential Model for Thinking Big

The course the University of Nebraska pursued in developing and establishing the Water for Food Institute can serve as a potential model for thinking about and doing big things. To sustain and enhance our research mission in these challenging economic times, we cannot afford to narrow our thinking. We began with envisioning how we could address one of the biggest, most critical societal challenges, assessing our strengths, and developing a multidisciplinary approach. We were fortunate in having strong, active leadership from NU President Milliken, who envisioned a system-wide institute, urged the involvement of all four campuses, and tirelessly pursued funding, and UNL Chancellor Harvey Perlman, who recognized the potential and scope of water for food and gave his full support and key resources to pursuing this big idea.

We built our credibility and our network by bringing key partners to campus as visiting speakers and through the conferences; by traveling to India, Sri Lanka, Stockholm, Delft, and other venues to learn from and engage potential partners; and through the usual routes of attending conferences, visiting federal agencies, foundations, and other potential funding sources.

Perhaps surprisingly, some of the most difficult work lies in engaging and getting buy-in from our own faculty. A great deal of work goes into transforming the "What's in it for me?" attitude into enthusiasm for what we can build together. But this is the work with the greatest dividends. The excitement and enthusiasm begin to build, and the faculty becomes a powerful force in creating programs and cooperative projects and building partnerships outside the university.

Again, those partnerships are critical. And a big idea like the Water for Food Institute offers a great opportunity for our neighboring universities, who also offer substantial expertise in the use of water for agriculture and a deep understanding of its importance, to partner with us in making a difference on this global issue. 